\title{
CONSTRUCTED WETLANDS IMPLEMENTATION IN KATHMANDU VALLEY, NEPAL
}

\author{
ZUZANA BOUKALOVÁ ${ }^{1,2}$, JAN TĚŠITEL ${ }^{2,3} \&$ BINOD DAS GURUNG $^{1,2}$ \\ ${ }^{1}$ METCENAS o.p.s., Czech Republic \\ ${ }^{2}$ Czech University of Life Sciences Prague, Czech Republic \\ ${ }^{3}$ AMBIS a. s., Czech Republic
}

\begin{abstract}
Constructed wetlands can be considered as a strategic nature-based wastewater treatment technology for Nepal, where the discharge of untreated wastewater into rivers, lakes or any other water body is a common practice and where the big wastewater treatment plants are not well functioning or are not sufficiently used. The successful implementation of constructed wetlands in Nepal is conditioned by many factors, which should be considered. Legislation is weak and hygienic standards are low; therefore, wastewater treatment is usually not a priority for city governments and private or public institutions, as well as for communities themselves. Under these circumstances, it is not an exception that it might be difficult to convince people to pay for constructed wetlands implementation and maintenance. Our paper discusses conditions influencing the applicability of constructed wetlands in the Kathmandu Valley, Nepal, by empirically analysing the best and bad practices of their application. The focus is paid to present the social situation and history of analysed communities and organisations. Implementation of constructed wetlands for schools is discussed as a special case, as well as the change of the communities' approach towards constructed wetlands' importance, as it appeared during the pandemic situation of COVID-19 in 2020.

Keywords: constructed wetlands, Kathmandu Valley, land management, communities, nature-based water treatment solutions, pollution control, Nepal, water resources management.
\end{abstract}

\section{INTRODUCTION}

Constructed wetlands are highly efficient in removing organic and insoluble substances. The construction and operation of them are both simple and cost effective, with low energy consumption (if any). In Europe, constructed wetlands are widely used as an effective, naturebased technology for municipal wastewater treatment both in cities and in rural areas. Even though this technology has all the attributes of a success story - relatively low investment costs and simple operation - its successful transfer to developing countries is not uncomplicated. The main reason for this is the social and cultural differences in these target countries.

In Nepal, the most suitable location for the operation of constructed wetlands is the Kathmandu Valley, where the population is concentrated in three big cities (Kathmandu, Lalitpur and Bhaktapur) with very varying conditions of living and wastewater management practices. The constructed wetlands could be, here, considered for the local solutions and support of the wastewater management practices out of reach of the big Wastewater Treatment Plants at Kodku (Patan), Sallaghari and Hanumanghat (Bhaktapur), Dhobighat (Kathmandu) and Guyesheshowri (Kathmandu), managed by the Government of Nepal via The Kathmandu Valley Wastewater Management Project [1], [2]. The constructed wetlands could be welcomed to provide sustainable wastewater treatment here for a number of households in areas where water retention at the landscape is needed, the groundwater level is continuously declining and the local hydrogeological situation is favourable for the water infiltration. 
The idea of our research in Kathmandu Valley, as well as this paper, is to review the recent situation of the constructed wetlands in the area. Next, find the circumstances that are influencing wetlands functioning and define the important issues for their successful operation and maintenance.

\section{CONSTRUCTED WETLANDS AND THEIR VEGETATION COVER IN NEPAL}

Constructed wetlands is a biological wastewater treatment technology designed to mimic processes found in natural wetland ecosystems. These systems use wetland plants, soils and their associated micro-organisms to remove contaminants from wastewater [3].

There are two main directions of flow in the subsurface flow wetlands: horizontal flow and vertical flow, both of which have certain advantages and limitations. By combining them, we get a hybrid system that complements each other [4]. In horizontal flow wetlands, the wastewater flows from the inlet in the bed to the outlet of the bed in a horizontal path. As the wastewater moves slowly through the porous substrate, it encounters anaerobic, aerobic and anoxic zones. For Nepal, the horizontal flow constructed wetlands are easier to be maintained successfully; however, the hybrid system could be better functioning in the developed areas in the cities, with limited space, e.g., for private houses or schools.

In addition to the right arrangement, proper vegetation cover that fits into local climate conditions is also crucial for constructed wetlands. In Nepal, we encountered several widely used plants, which were selected based on their presence in the proximity of the implementation site and, of course, also based on their capacity to eliminate water contamination. These especially included calamus, reed beds and hyacinth.

All these vegetation species were documented by us during our field survey in Nepal. Reed beds were found to be most widespread, as this plant is common in the Kathmandu Valley and highly suitable for constructed wetlands because it can be procured at a low cost. The only problem we found in using this plant was that it is not always timely cut and kept in an effective condition; it was usually found overgrown and dry, with limited performance, as, e.g., in the case of the constructed wetland in the Namo Budha tourist resort. Hyacinths were found only in two cases, once in a non-functioning wetland in Kirtipur and once at a private home, where hyacinths were also part of the garden ornamental planting. Calamus is very common in the Lalitpur area; therefore, it was also used for the functional constructed wetland in Dhapakel. However, according to the oral testimony by Ms. Sarala Budhathoki (see Fig. 1), who is in charge of the wetland maintenance, calamus is not entirely suitable for this use due to its medicinal qualities: local people pluck the calamus plants to make herbal infusions and ointments. On the one hand, this reduces the presence of the plant in the wetland and, on the other hand, such calamus plants (as, e.g., in the case of Dhapakel; see Fig. 2) are not suitable for medicinal uses as they may accumulate contaminants from the wastewater being treated.

In constructed wetlands, the vegetation cover performs various important functions that may differ depending on the type of constructed wetland. However, plants in the constructed wetland help decompose and remove insoluble as well as soluble substances mainly of organic origin from wastewater. This takes place both directly (through absorption) and indirectly (e.g., by creating conditions for biofilm growth). The plants also play a mechanical role: plant parts, particularly those found above ground, act as a certain kind of barrier that may affect wind speed, thereby altering the microclimate to some degree. In wintertime, plant residuals on wetland surface may act as an insulation layer [5].

Wetland plants are capable of absorbing some substances from wastewater - nutrients (such as nitrogen and phosphorus), which are then used for the plants' own benefit. Thus, 
nitrogen and phosphorus removal from wastewater passing through the plant section of the constructed wetland takes place.

For several biological processes and chemical reactions taking place in constructed wetlands, sufficient oxygen supply is necessary, which supports the existence of aerobic bacteria and thereby also the elimination of biological contaminants. The microorganisms assisting in wastewater purification are mostly bound to the roots of the wetland plants, where they are indispensable for an active nitrification and denitrification process. Nitrification is defined as the biological oxidation of ammonia to nitrates through an intermediate level represented by nitrites. This reaction takes place in the aerobic layer of the soil or in the vicinity of the plants' root systems and requires aerobic conditions [6]. The rate of the nitrification process typically depends on the supply of ammonia nitrogen in the oxygenated zones in the vicinity of the roots, size of these zones, $\mathrm{pH}$, temperature, the presence of nitrifying bacteria and water alkalinity. During nitrification in constructed wetlands, about $4.3 \mathrm{mg}$ of oxygen is consumed per $1 \mathrm{mg}$ of ammonia nitrogen, while hydrogen ions are released, bringing about the acidification of water [7].

Denitrification is a process, through which nitrates are broken down to gaseous nitrogen (or nitrous oxide) and ammonia by bacterial action. Unlike nitrification, denitrification takes place in anoxic conditions (i.e., in the absence of oxygen). During this process, hydroxide ions are released, which means that the water becomes more alkaline.

\section{MAINTENANCE PRACTICES OF THE CONSTRUCTED WETLANDS IN NEPAL}

Even though constructed wetlands have proven effective for treating different kinds of wastewater, there are still some challenges in the promotion of them. Despite constructed wetlands being a low-cost technology, it might be difficult to convince people to take basic care about the constructed wetlands and pay to treat their wastewater rather than just discharging it into the river (as there is no legislation and penalties to 'convince' them) [8].

Paradoxically, the COVID-19 pandemic in 2020 has helped to promote the benefits of constructed wetlands, as communities fear the spread of the virus through wastewater, and household water treated by constructed wetlands is seen as a source of safe water suitable both for farming and for other uses such as irrigation of gardens, laundry and cleaning activities in the household. As part of a questionnaire survey, we found this attitude, e.g., in the case of the Lalithpur constructed wetland on the Dhapakel site. In 2019, i.e., before the pandemic, when the local wetland was constructed and its operation started, the interest of the neighbouring citizens in its importance was scarce. The wetland was established under the supervision of the Chairperson of the ward on the premises of the Municipal Ward Office in Dhapakel using horizontal flow of wastewater through a permeable substrate planted with wetland plants - calamus vegetation. It was designed for wastewater from offices, a nearby located police station and the local community's training centre for about 20-25 people [9].

The water treated by the wetland is drained into a pit and subsequently infiltrated into a shallow aquifer, as this is a sustainable wastewater management solution without creating contamination of the surrounding land. At the same time, this solution will, in the long run, enhance groundwater yield within a larger area of interest. During the year the wetland has been in operation, the information about the purpose of the wetland had spread through the local community and, during a field survey on 17 October 2020, an opinion was officially passed around that the wetland was necessary for obtaining virus-safe (that is COVID-19-safe) water for farming. The wetland is in good shape and is managed by Ms. Sarala Budhathoki, Social Mobilizer of Ward Office, living next to the ward office. During 


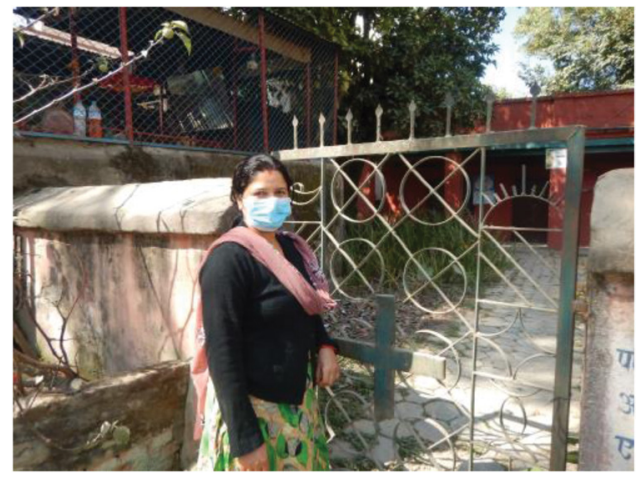

Figure 1: Ms. Sarala Budhathoki in front of the Dhapakel constructed wetland.

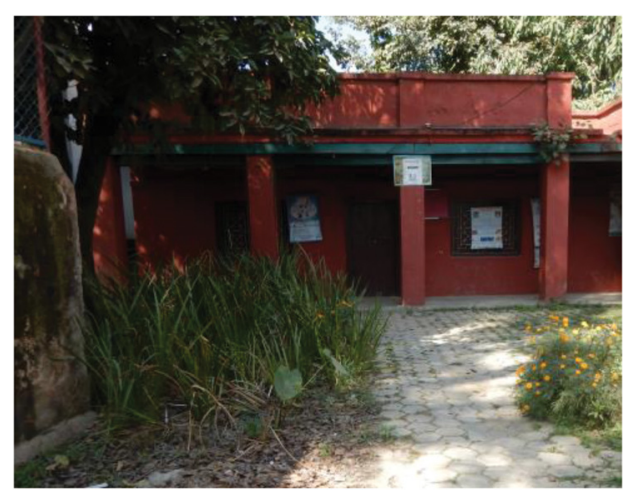

Figure 2: Dhapakel constructed wetland in October 2020.

a conversation, she clearly articulated the new approach: 'If we could establish this system of constructed wetlands in the community and household level, water can be used for the irrigation. And this water is safer and less likely to be catalyst for spreading of virus. So that farmers do not need to rely on other sources of water where the high chance of spreading of virus through water exists.'

Before the COVID-19 pandemic, the communities' interest in keeping the constructed wetlands in good shape on their own was far from being a reality. Even though the maintenance of constructed wetlands and their surroundings is simple and not energy consuming, requiring only minimum expenses (such as for obtaining or purchasing the necessary material for their construction, cleaning of the wetland filters and sand every 7 to 10 years, as is necessary, modification of the wetland plants and their exchange or, if needed, occasional sampling of water released from the wetlands to monitor its quality), it is not common. In case these expenses (or the salary of the wetland manager) were not covered from the community sources or subsidies or if no clear economic benefits were associated with wetland maintenance (such as the use of biogas at sites with a pond for biological pre-treatment where digestion of organic waste takes place prior to entering the wetland), the interest in wetland maintenance was declining up to the point of vanishing completely (as was observed in the case of the Kirtipur community; please see the chapter 'Story of the Kirtipur community').

In times of the pandemic, the economic benefits have been outmatched by the fear of the COVID-19 virus. The communities' demand for 'wholesome water without the virus' was the main motivation factor for accepting and maintaining the constructed wetland. The communities are now capable of allocating the necessary funds for the maintenance of the wetland to ensure and oversee its proper operation.

The question is how long this situation is going to last after the COVID-19 pandemic is over.

\section{FIELD RESEARCH IN THE KATHMANDU VALLEY}

The sociological research was aimed at getting an in-depth understanding of the situation, as well as the factors supposed to influence it. Therefore, a qualitative approach was used. Doing so, we were in line with approaches applied to understand ecosystem services implementation strategies in general and constructed wetlands in particular [10-15]. The sociological 
field research was based primarily on the application of qualitative methods. Empirical data were gathered by the use of semi-standardized interviews with particular stakeholders. In the situation of the absence of an effective state regulatory framework in Nepal [16-18], local socio-economic conditions were considered the most important factor for the successful implementation of constructed wetlands in situ. Therefore, the interviews aimed to reveal the socio-economic and cultural situations in particular spots, as well as the role of particular stakeholders in the process of constructed wetland building and operating or declining.

A particular constructed wetland associating all the above-mentioned types of stakeholders was defined as the main unit of analysis. The situation (the particular constructed wetland) was considered the basic unit of the analysis, in which three principal actors directly participated:

- users of constructed wetlands (communities, institutions and private houses)

- local authorities setting the political context (mayor offices and chairpersons of pertinent commissions) and

- NGOs, local to international, channelling financial sources and supervising the building and operation of constructed wetlands.

Sixty constructed wetlands situated in the Kathmandu valley, mentioned on the list produced by the Environment and Public Health Organization (ENPHO) [19] and in the other sources, were used as the point of departure in identifying the sample. When checking the reality, however, we were able to find only 23 of them. All were included in the sample. The sample represented a relatively wide variety of situations, as can be seen in Table 1 .

The field campaign - visit of particular constructed wetlands - was realised by the authors in September 2019. There were three interviewers in the team working jointly, two Czech and one Nepali who served as an 'interface' between west science and the local situation, culturally far different from that in Europe. To minimize the danger of information loss or potential misinterpretation of data, the interviews were audio recorded in Nepali (see Fig. 3), transcribed verbatim and subsequently translated into English. To complete the picture, photo documentation was done, as, e.g., in the case of the interview with the Biogas Committee of the Sano Khokana (see Fig. 4). The text was subsequently analysed using thematic analysis.

Table 1: Structure of the sample.

\begin{tabular}{lllll}
\hline \multirow{2}{*}{ Type of user } & \multicolumn{4}{l}{ State of the Constructed Wetlands } \\
\cline { 2 - 5 } & Functioning & Partly functioning & Not functioning & Total \\
\hline Schools & 1 & 1 & 3 & $\mathbf{5}$ \\
Communities & 1 & 1 & 3 & $\mathbf{5}$ \\
Private houses & 1 & 1 & 1 & $\mathbf{3}$ \\
Research institutions & 2 & & 4 & $\mathbf{6}$ \\
Hospitals & 1 & & 1 & $\mathbf{2}$ \\
Monastery & & & 1 & $\mathbf{1}$ \\
Industry & 1 & $\mathbf{3}$ & $\mathbf{1 3}$ & $\mathbf{1}$ \\
In total & $\mathbf{7}$ & & $\mathbf{2 3}$ \\
\hline
\end{tabular}




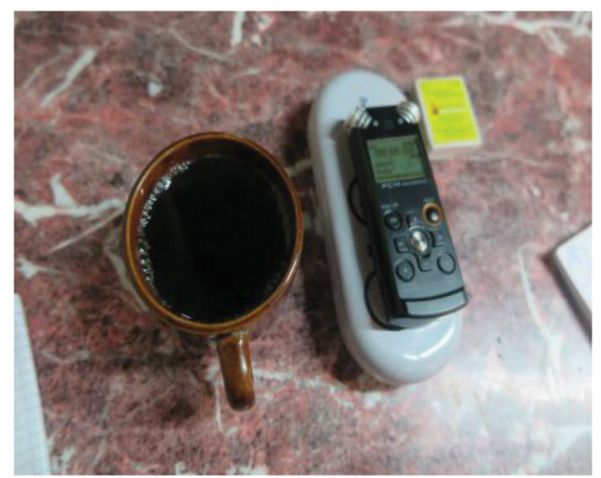

Figure 3: Sunga Thimi community - the audio recording of the interviews.

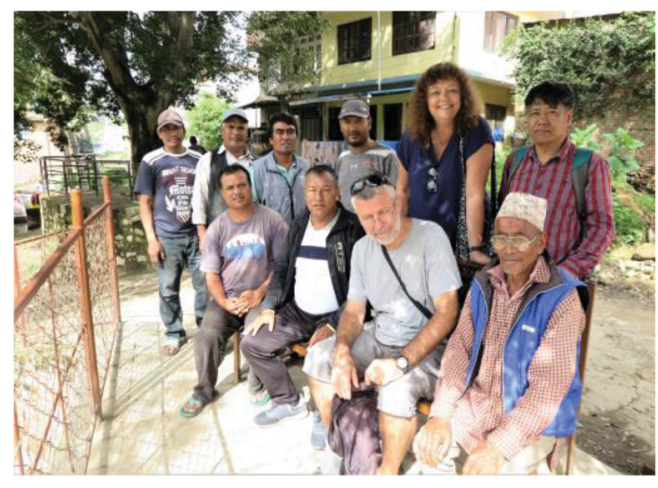

Figure 4: Interview with the Biogas Committee of the Sano Khokana constructed wetland.

The questions we asked in the interviews focused on the status of the constructed wetland (if it is functional, semi-functional or not functional) and in the case of the functional and semi-functional constructed wetlands, we discussed the following areas:

- Who owns the constructed wetland and for whom it was constructed?

- Socio-economic description of the community/settlement/household (in terms of caste, ethnic group and economic class), length of stay at the spot (permanent-immigrants) and number of users

- Which specific technology was used for the implementation of the constructed wetlands at the site? Why was this specific technology chosen or, if this is the case, who had recommended it and why? In the Kathmandu Valley, there are two main organisations dealing with the implementation of constructed wetlands (the ENPHO [19], who has been pioneering the implementation of constructed wetlands in Nepal, in cooperation with the Austrian University of Bodenkultur, Vienna, since 1997 [20], and Lumanti, a non-profit making organization dedicated to the alleviation of poverty in Nepal through the improvement of shelter condition). Both of them have their own ways, financial resources and intentions as to why and how to promote constructed wetlands. In the case of ENPHO, these include environment protection support, municipal wastewater treatment and the supply of 'healthy' water for households and permanent communities. Lumanti, on the other hand, typically builds constructed wetlands as part of new housing units for families in need, which, after they settle in, constitute an entirely new community with their neighbours.

- Who takes care or is responsible for the constructed wetland being operational (what 'responsible' means in practical terms and what activities are expected to be 'responsible'. Do they have a management/user committee? If yes, how it was formed and what are its main activities/responsibilities related to the constructed wetland? Do they manage the constructed wetland as well financially?)?

- Involved end users and financial source (who initiated wetland construction and why, what financial source were used and why these particular ones, etc.)

- Community management aspects - do they want to keep the constructed wetland operational and why (importance of constructed wetlands for them; advantages compared to other solutions of wastewater treatment, including zero treatment)? Do they know about/ are in contact with other cases where the technology of constructed wetlands is/was used as a technology for wastewater treatment? 
- Major problems/challenges related to the constructed wetland operation, if any (in the past, at present or expected). What would they like to change, and could they do it themselves or is an external assistance expected/needed?

- How do they see the future of their constructed wetland system? How do you share your good and bad experiences with other areas/people if at all?

In the case of the non-functional constructed wetland, we discussed the following areas:

- Why the constructed wetland stopped working? What were the reasons (low efficiency of applied technology, difficulties in maintaining it/poor maintaining, economy or any other reason, including social and cultural/ethnical barriers)?

- What kind of technology for the treatment of wastewater they use instead, if any (including no-treatment)? Is the newly applied technology better and in which aspects?

- Is there any chance to put the constructed wetland into operation again? If yes, under which conditions/circumstances? Do they plan to do it?

The results suggest that it is the motivation (or lack of it) of users to have the constructed wetland that represents the major factor responsible for the implementation of this technology. Relatedly, community involvement and clearly defined personal responsibility for maintaining the wetland decide as a rule on keeping the wetland in operation in the long run. In this respect, the situation in Nepal does not differ profoundly from the situation in the Czech Republic.

Lack of necessary land for constructed wetland implementation is another challenge in Kathmandu city, where the private household owners are interested in sustainable and economically feasible solutions to keep the water for their use. Many of the households have land just for their building construction and no space for the constructed wetland organisation.

The consideration of constructed wetlands as a low maintenance technology sometimes leads to carelessness during operation and maintenance [16]. However, maybe the situation will change after the pandemic of COVID-19?

\section{STORY OF THE KIRTIPUR COMMUNITY}

The Kirtipur community in Kathmandu is formed by the 44 poor internally displaced families from other areas after road-widening activities. They are living in small houses built by the Lumanti non-profit organization as a complex including a constructed wetland and a rain harvesting system.

As part of the field survey, we visited the constructed wetland built for the needs of the Kirtipur community both in 2018 and 2019. On both occasions, we found that the wetland was functioning to a very limited degree. The constructed wetland system on this site is composed of two horizontal artificial wetlands: an upper (bigger) wetland and a lower (smaller) wetland, from which water flows freely into a ditch used for the irrigation of the farmland, which, however, is not owned by the community.

Prior to entering the wetlands, wastewater flows into a settling basin where mechanical and biological contaminants are separated and biogas is produced. In 2018, biogas was used by two households of community members who were voluntarily taking care of the constructed wetland operation, though to a limited degree permitted by their religious belief. In fact, the Kirtipur community members belong to a caste that is forbidden from touching waste. As a result, they are not allowed to clean the septic tank and waste produced by the mechanical wastewater pre-treatment at the inlet into the constructed wetland system. The contamination is building up in the basin, compromising the performance of the upper wetland. The waste from the pre-treatment basin may only be hauled away by an external subcontractor, whose 
services need to be paid for. This does not suit the community, so they prefer to leave the waste in place. The biogas production has also been affected by the poor management of the separation basin. In 2019, biogas was not used anymore and, therefore, this motivation factor for the constructed wetland maintenance manager disappeared as well. During the 2019 visit, no one was found to claim direct responsibility for the wetland maintenance.

The bigger constructed wetland is situated at the centre of the community square (see Figs. 5 and 6); the treated water from this wetland flows horizontally into a lower-lying, noodleshaped wetland in the lower part of the community village. In 2018, due to monsoon rains and clogging, the central wetland had been transformed into a pond, from which only a small number of hyacinths were emerging, while a lot of garbage, food scraps and plastic bags were floating around. In 2019, new gravel was placed in the upper wetland, which, however, did not significantly enhance its performance: there was a single small island of vegetation in the entire 'wetland', while the other plants had nearly disappeared. Water from this area filters by gravity along preferential pathways through the gravel filter into the lower-lying wetland, which has a corresponding amount of reed beds. However, the performance of this wetland is again severely affected by clogging. From this wetland, muddy water with an almost imperceptible smell flows out into the irrigation ditch.

The Lumanti organisation, which built the community village along with the constructed wetland and a biogas plant, apparently underestimated the social situation of families from the Kirtipur community. These families are randomly settled together without having previous relationships; thus, the community is new, and this results in their attitude towards the common property. In addition to that, the Kirtipur community members did not participate in the construction of the constructed wetland. They received it for free along with the community membership (which was obtained for a financial contribution for being allowed to live in a small house within the community).

In Kathmandu and its surroundings, Lumanti engages in active protection of the quality of water in the Bagmati River and environmental sustainability. The organisation also assisted in establishing a constructed wetland for the Sano Khokona community that has been living together for a long time. In this case, the initial intention was successfully carried out. The constructed wetland has been operating successfully for more than 15 years, including a biogas plant providing biogas for six households. The whole constructed wetland system is kept functional thanks to the activities of the Biogas Committee, which consists of nine

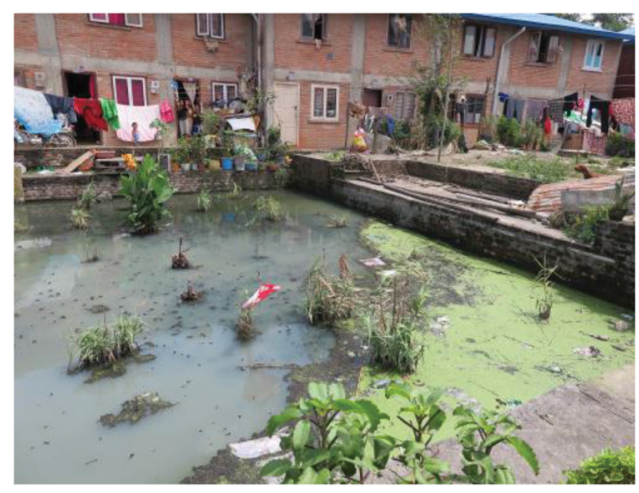

Figure 5: Kirtipur upper constructed wetland in the September 2018.

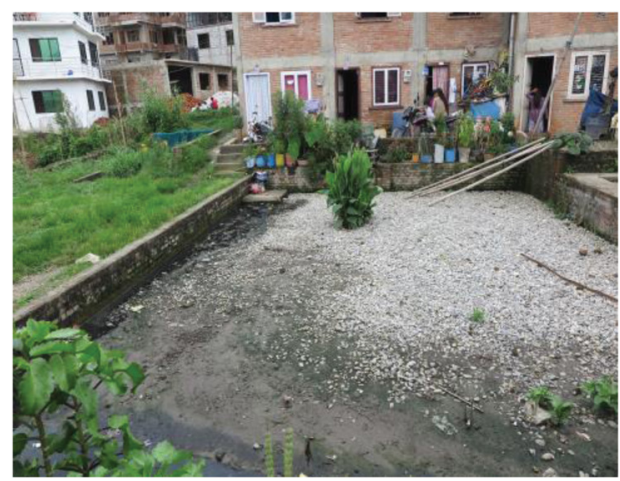

Figure 6: Kirtipur upper constructed wetland in the September 2019. 
members on a voluntary basis. What is also positive for the sustainability of the system is the fact that the constructed wetland was built using $80 \%$ of the funds from the Lumanti nonprofit organisation and 20\% from the community's own sources in the form of local people's labour. The Biogas Committee members also profit from the biogas production.

This example clearly shows that the motivational component is not to be underestimated in environmental protection as, for the majority of less-educated Nepalese, high-quality environment in itself is not a sufficient reward.

\section{THE SPECIAL CASE: SCHOOLS IN THE KATHMANDU VALLEY}

In the Kathmandu Valley, a special case of model users are bigger schools, where constructed wetlands mostly work well. As two cases that are different (as to their focus and ways of teaching) and yet similar (in their necessity of making themselves visible and the tendency towards addressing environmental issues), we selected two schools running similar constructed wetlands composed of a sedimentation tank where the separation of the solid and liquid parts takes place, followed by an anaerobic baffled reactor and constructed wetlands with emerged vegetation. Satya Sai Sikshya Sadan School is an academic school with religious tradition. The first of the series of Sri Sathya Sai Schools was founded by Master Sai Baba in India in 1968; in the same tradition of the five pillars of Truth, Right-conduct, Peace, Love and Non-violence, the school at Tokha in Kathmandu was established in 2014. At the school, about 550 residents, including teachers and personnel, are living, out of which there are about 400 schoolchildren from 56 districts of Nepal. There is no sewerage in the school. As a result, a decision was made during the construction of the school that, in accordance with its spiritual and environmental tradition, constructed wetlands would be set up for wastewater treatment, serving at the same time as a technology for infiltration of the treated water into the shallow aquifer to enhance the recharge of the exploitable groundwater in a broader area. The constructed wetland system connected with a rainwater harvesting system on the school premises is also used for educational purposes both for their own students and as a model for other schools and institutions. Financing of the constructed wetlands (their construction and maintenance) is done from the school's own local funds (particularly school fees), while the laboratories of the ENPHO organisation help with water quality monitoring. The constructed wetlands are fully functional there (see Fig. 7), and the school is proud of

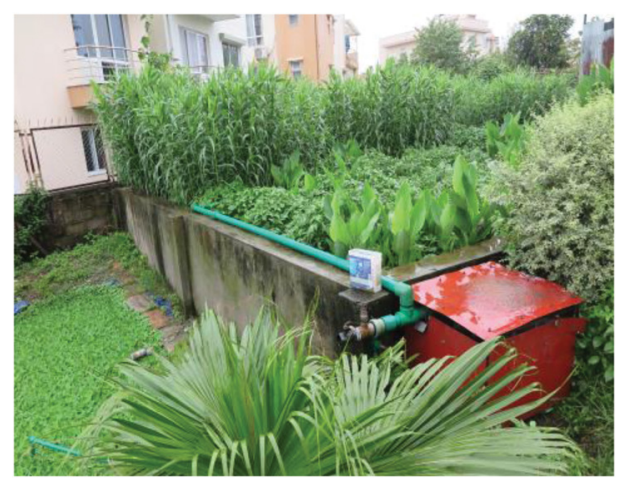

Figure 7: Satya Sai Sikshya Sadan school the well-functioning constructed wetland, September 2019.

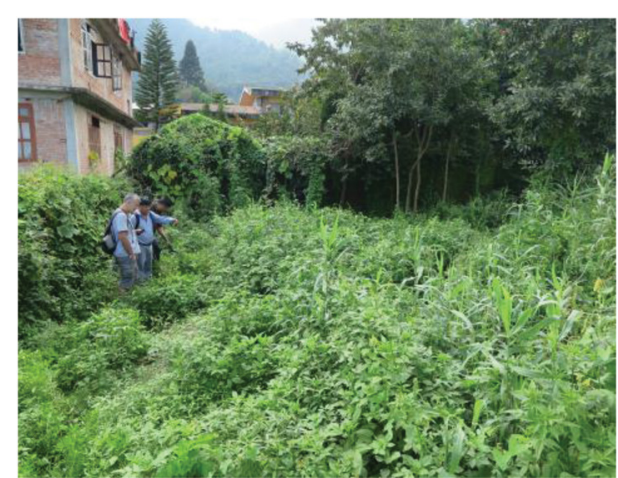

Figure 8: Shuvatara school semi-functioning constructed wetland, September 2018. 
them. The constructed wetlands on the Satya Sai Sikshya Sadan school premises were presented to us by the school principal himself, who is also its highest religious representative. The school motto is: 'Water is life!'.

Another example of schools where wastewater from bathrooms, toilets and the kitchen are released into constructed wetlands is Shuvatara International School (private boarding high school) in Lalitpur (see Fig. 8). It is a school for young people from wealthy families (attended by about 700 students) where constructed wetlands and, generally, environmental education are regarded as a token of good quality, increasing the school's prestige. The proprietor of the school is one of the richest businesspeople in Kathmandu who, among other things, owns a chain of restaurants and snack bars where only deaf-mute staff are employed. The constructed wetlands on the school premises are in good shape. Moreover, there is an appointed person responsible for the maintenance and monitoring of the treated water quality. Even though the constructed wetlands on the premises were working only partially, as part of them was being renovated, the water released from them was clear and absolutely without smell. This treated water was then drained by a ditch running along the school premises to the close-by agricultural fields. Prestigious schools in Nepal are a good environment for the construction and operation of constructed wetlands and, in this context, maybe generally held up as an example. It is in the interest of the schools to maintain their constructed wetlands because they are part of their image and the reason why parents - thanks to environmental education - choose them for their children. However, it still needs to be examined how school managements have dealt with the limited operation of the constructed wetlands and whether the constructed wetlands designed for several hundreds of students and staff are still in operation after unexpected cases of lockdown, as in 2020-2021, during the COVID-19 pandemic when schools, with very short interruptions, were closed by state orders from spring 2020 until 4 January 2021. During the lockdown, the schools were not in operation and wastewater was not produced. Therefore, it is crucial to determine whether the constructed wetlands have not been damaged due to insufficient horizontal flow and how school managers have dealt with this situation.

Another suitable type of site that is specific for Nepal (but is not at the centre of interest of this paper) is the implementation of constructed wetlands and generally nature-based technologies at the centres for spiritual practice and yoga for foreign clients and tourist resorts in general, where it is desirable to demonstrate a connection to nature (as an example of partial success, the Namo Budha Resort and Chandra Ban Eco Resort can be mentioned, see Figs. 9 and 10).

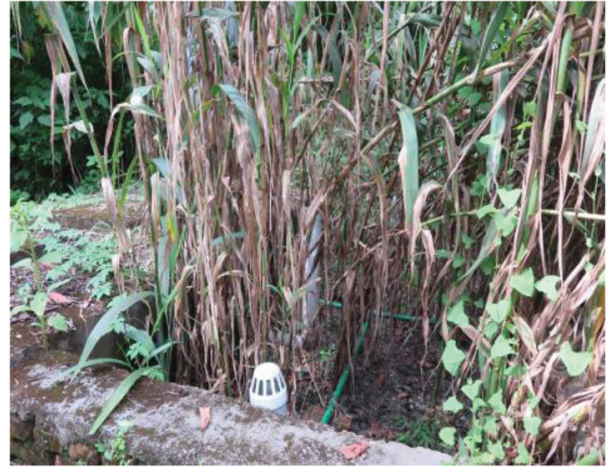

Figure 9: Semi-functioning constructed wetland in the Namo Budha tourist resort, September 2019.

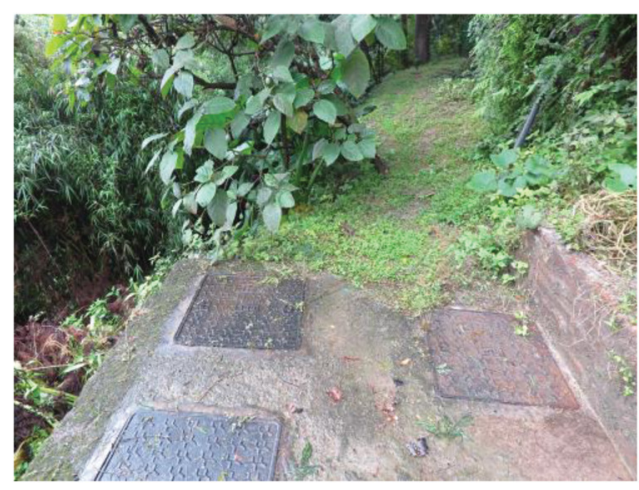

Figure 10: Place of the not well-functioning constructed wetland at Chandra Ban Eco Resort, September 2019. 


\section{CONCLUSIONS}

There is no doubt that constructed wetlands are an important part of water management in the Kathmandu Valley and can - in an environment with lacking state and legislative wastewater management - at least partially meet the demand for 'healthy' water for farming and service purposes within small communities and thus play an active part in environment protection.

In private schools, e.g., the presence of a constructed wetland may enhance the school's reputation, which will reflect in the students' increased interest in studying there and, at the same time, ensure appropriate education of the students in preserving a high-quality environment for life (as an example, a very successful constructed wetland and rainwater harvesting system in the Satya Sai Sikshya Sadan school can be mentioned).

The other highly suitable site for the constructed wetlands building and operation are municipal premises - the success story of Dhapakel could be mentioned. It is very important that the Chairperson and/or the manager of the constructed wetlands is open to innovation and respected by the local communities.

Another suitable type of site that is specific to Nepal is the implementation of constructed wetlands in tourist centres for foreign clients.

The COVID-19 pandemic has paradoxically helped promote constructed wetlands at the level of communities, which previously did not pay much attention to the environmental aspects of household wastewater treatment by nature-based technologies. During the pandemic, economic benefits (such as extra income or source of biogas for those who look after the wetlands), which are usually crucial for long-term wetland management, have been overridden by the fear of the virus and its spread by water. Overnight, the demand for "healthy water without virus' has become the main motivation for the maintenance of constructed wetlands. Water purified by constructed wetlands is considered safe and used for the irrigation of agricultural crops or gardens by the communities.

\section{ACKNOWLEDGEMENTS}

This paper was developed thanks to the INTER-COST project 'Natural Based Solutions for water management in cities', financed by the Ministry of Education, Young and Sports, Czech Republic.

\section{REFERENCES}

[1] Green, H., Poh, S-Ch. \& Richards, A., Wastewater Treatment in Kathmandu, Nepal, Massachusetts Institute of Technology, USA, available at http://web.mit.edu/watsan/ Docs/Student\%20Reports/Nepal/NepalGroupReport2003-Wastewater.pdf, 2003.

[2] NEP: Kathmandu Valley Wastewater Management Project, Kathmandu Upatyaka Khanepani Limited Project Implementation Directorate Anamnagar, Kathmandu, available at http://www.kuklpid.org.np/kukl/, 2018.

[3] Tuladhar, B., Shrestha, P. \& Shrestha, R., Decentralised wastewater management using constructed wetlands, Urban Sanitation, ENPHO, pp. 86-94, Nepal, 2008.

[4] Yalcuk, A. \& Ugurlu, A., Comparison of horizontal and vertical constructed wetland systems for landfill leachate treatment. Bioresource Technology, 100, pp. 2521-2526, 2009. www.elsevier.com/locate/biortech. https://doi.org/10.1016/j.biortech.2008.11.029

[5] Brix, H., Do macrophytes play a role in constructed treatment wetlands?. Water Science and Technology, 35(5), pp. 11-17, 1997. https://doi.org/10.1016/S0273-1223(97)00047-4

[6] Šálek, J., Přírodní zpuisoby čištění odpadních vod. PC-DIR: Brno, 1995.

[7] Pytl, V., Příručka provozovatele čistírny odpadních vod. Medim: Libeznice, 2012. 
[8] Boukalova, Z., Těšitel, J. \& Gurung, D.B., Nature-based water treatment solutions and their successful implementation in Kathmandu valley, Nepal. WIT Transactions on Ecology and the Environment, 157, pp. 121-132, 2020. https://doi.org/10.2495/ WP200111

[9] Boukalova, Z., Těšitel J. \& Gurung, D.B., Constructed wetlands and their implementation on private and public land in Kathmandu valley, Nepal. WIT Transactions on Ecology and the Environment, 229, pp. 1-8, 2019. https://doi.org/10.2495/WRM190011

[10] Clare, S., Krogman, N., Foote, L. \& Lemphers, N., Where is the avoidance in the implementation of wetland law and policy? Wetlands Ecological Management, 19, pp. 165-182, 2011. https://doi.org/10.1007/s11273-011-9209-3

[11] Balvanera, P., et al. Ecosystem services research in Latin America: the state of the art, Ecosystem Services, 2, pp. 56-70, 2012. https://doi.org/10.1016/j.ecoser.2012.09.006

[12] Denny, P., Implementation of constructed wetlands in developing countries. Water Science and Technology, 35(5), pp. 27-34, 1997. https://doi.org/10.1016/S02731223(97)00049-8

[13] Everard, M., Harrington, R. \& McInnes, R. J., Facilitating implementation of landscape-scale water management: The integrated constructed wetland concept. Ecosystem Services, 2, pp. 27-37, 2012. https://doi.org/10.1016/j.ecoser.2012.08.001

[14] Hansson, A., Pedersen, E. \& Weisner, S. E. B., Landowners' incentives for constructing wetlands in an agricultural area in south Sweden. Journal of Environmental Management, 113, pp. 271-278, 2012. https://doi.org/10.1016/j.ecoser.2012.08.001

[15] Balkema, A., Njau, K. N., Romijn, H. \& Ruijter, R., Socio-economic analysis of constructed wetlands systems for hygienic sanitation in Tanzania. Water Practice and Technology, 5(1), pp. 127-139, 2010. https://doi.org/10.2166/wpt.2010.022

[16] Shrestha, R.R., Application of constructed wetlands for wastewater treatment in Nepal - Dissertation, University of Agricultural Sciences, Vienna Austria Institute for Water Provision, Water Ecology and Waste Management, Department for Sanitary Engineering and Water Pollution Control, 1999.

[17] Pudasaini, K., Performance of wastewater treatment plants (BASP and SWTP) in Kathmandu valley: case study of Bagmati area sewerage treatment plant (BASP) and Sunga wastewater treatment plant (SWTP) - Master's Thesis, Delft-IHE, Institute of Water Education, 2008.

[18] Murthy,V. K., Khanal, S.N., Majumder, A.K., Weiss, A., Shrestha, D. \& Maharjan, S., Assessment of performance characteristics of some constructed wetlands in Nepal, Kalmar Eco-Tech '07 Kalmar Sweden, and November 26-28, 2007.

[19] Environment \& Public Health Organization (ENPHO) website (http://demo.crossovernepal.com/NP00100/?iec=factsheets).

[20] Shrestha, D. \& Maharjan, S., Constructed wetland: a solution for wastewater treatment. Hydro Nepal: Journal of Water, Energy and Environment, 5, pp. 42-45, 2009. https:// doi.org/10.3126/hn.v5i0.2486 